\title{
Reconstructing the polder: negotiating property rights and 'blue' functions for land
}

\section{Dik Roth}

Law and Governance Group,

Wageningen University and Research Centre,

Hollandseweg 1, $6706 \mathrm{KN}$ Wageningen, The Netherlands

E-mail: dik.roth@wur.nl

*Corresponding author

\section{Madelinde Winnubst}

Centre for Sustainable Management of Resources, Radboud University Nijmegen,

Toernooiveld 1, 6525 ED Nijmegen, The Netherlands

E-mail: m.winnubst@science.ru.nl

\begin{abstract}
Dikes were the core of Dutch river flood protection. Near-floods in 1993 and 1995 and debates about climate change, however, led to a rethinking of existing approaches. In the policy directive 'Room for the River' the focus has shifted from infrastructure (dikes) to spatial measures (bypasses, dike relocations, 'green' rivers). While people and land used to be separated from water by dikes, this new policy intensifies water-society interactions. This has important social, spatial and property consequences for inhabitants, and requires a style of governance based on negotiations between the government and societal actors. In this article, we discuss the case of the Overdiep polder along the river Meuse where a 'Room for the River' project is being implemented. The inhabitants have developed a plan for a spatial redesign of the polder to make peak water retention possible. We discuss key aspects of the complex negotiations about property, security and continuity of living and farming in the polder.
\end{abstract}

Keywords: farming; flood risk management; infrastructural and spatial measures; property rights; security; The Netherlands.

Reference to this paper should be made as follows: Roth, D. and Winnubst, M. (2009) 'Reconstructing the polder: negotiating property rights and 'blue' functions for land', Int. J. Agricultural Resources, Governance and Ecology, Vol. 8, No. 1, pp.37-56.

Biographical notes: Dik Roth is a Social Anthropologist affiliated to the Law and Governance Group of Wageningen University and Research Centre (WUR), Wageningen, The Netherlands. His teaching and research focus on issues of natural resources management. His current research deals, among others, with changing river flood policy in The Netherlands.

Madelinde Winnubst is a Social Anthropologist. She is a $\mathrm{PhD}$ candidate and a Researcher at the Radboud University Nijmegen (RU) for the European project Freude am Fluss. Her research concentrates on the social interaction between government and local groups in flood risk management and whether this leads to conflict, evasion, accommodation or collaboration.

Copyright (C) 2009 Inderscience Enterprises Ltd. 


\section{Introduction: negotiating spatial flood protection and its property consequences}

\subsection{From infrastructural to spatial solutions}

In 1993 and 1995, extreme discharges and near-floods of the rivers Rhine and Meuse occurred in the Netherlands. In combination with emerging debates about climate change, these events triggered discussions about flood risk and protection policies. After the 1953 sea flood, the Dutch had embarked on an ambitious safety plan for sea floods, the 'Delta Works'. In the shadow of this prestigious programme, river flood protection had a relatively low priority. After 1953, a safety standard for flood-prone areas had been introduced. Later, four major safety levels were prescribed, depending on location, population, investments inside the dikes and probability of (salt- or fresh-water) flooding. These safety levels relate to probabilities of exceeding design conditions. Both the safety levels and the location of the dike rings were further specified in the 1997 Law on Flood Defence (Kwadijk et al., 2001; van der Most and Wehrung, 2005; Samuels, Klijn and Dijkman 2006).

Thus, river management was primarily based on dike enhancement: taming the rivers by a separation between people and land, and the water squeezed in between dikes. The Directorate-General of Public Works and Water Management (Rijkswaterstaat) of the Ministry of Transport, Public Works and Water Management (Ministerie van Verkeer en Waterstaa - MVW) ruled by a 'command and control' approach based on infrastructural engineering works (Wolsink, 2006). Until the 1990s, the Dutch felt safe behind ever higher and stronger dikes. If this protection strategy was debated at all, it was not because of doubts about the kind of security it provided but rather because the ever more robust dikes were seen as a threat to cultural and landscape values (Wiering and Arts, 2006).

However, the high water of the 1990s and the climate debate generated criticism of the level of security provided by dikes and the system of norms and design discharges. After implementation of a crash programme of dike reinforcement that could now politically afford to marginalise earlier 'green' protests, the focus shifted from technicalinfrastructural interventions (dikes) towards combinations of these with spatial measures (Wiering and Driessen, 2001; van Stokkom, Smits and Leuven 2005). The policy directive 'Room for the River' (Ruimte voor de Rivier) was developed in the course of the 1990s. It aims at a package of structural spatial (and infrastructural) measures to increase protection against flooding (dike relocation, lowering of flood plains, retention, 'green rivers' and 'bypasses'). It should prepare the Dutch rivers to floods up to $16,000 \mathrm{~m}^{3} \mathrm{sec}^{-1}$ by $2015 .^{1}$ A large number of 'Room for the River' projects will be implemented along the major river branches (Rijn, Waal, IJssel, Meuse; MVW, 2007). ${ }^{2}$

In many ways, this marks a break with the past (Wiering and Arts, 2006). First, while people used to be separated from the river, in the future they will experience a more direct interaction with it. They will have to adapt their perceptions of risk and security, their agricultural practices and ways of life to this new reality. Second, it entails a shift from interventions in the floodplains between the dikes towards activities inside the dikes, where people live. In the densely populated Netherlands, this inevitably puts increasing pressure on scarce space, and will have impact on areas along the rivers (Wiering and Driessen, 2001; Wiering and Immink, 2006). Third, this requires a style of governance based on reaching negotiated solutions with local inhabitants, government 
administrations at various levels, ministries and agencies; in short, a negotiated approach including participatory design and implementation.

This has never been the strongest point of Rijkswaterstaat (see van der Werff (2004) for 'Room for the River'; Roth and Warner (2007) for 'calamity polders'). Between 2000 and 2005, it paid a high price for this attitude. In the framework of developing spatial protection measures it had made plans to establish so-called 'calamity polders' (noodoverloopgebieden). Use of the polders for water storage during extreme river discharges should protect the densely populated and economically important western Netherlands. These plans, developed without paying serious attention to interaction with local inhabitants, caused fierce protests in one of the selected areas (Roth, Warner and Winnubst, 2006; Roth and Warner, 2007). In 2005, the government was finally forced to leave the calamity polder option for two out of three selected areas. The affair increased public awareness of the need for policy changes, but also local distrust of government plans. It also increased the awareness of Rijkswaterstaat policy makers that bypassing inhabitants affected by such measures is a recipe for trouble (Roth, Warner and Winnubst 2006; Wiering and Arts 2006; Roth and Warner, 2007).

\subsection{A focus on rural property}

These changes are crucially connected to broader processes of revalorisation and renegotiation of rural property. Changing approaches to flood protection as a public good in a highly urbanised society attach new values to rural property. In this process, new forms of multifunctional land use are emerging: as 'blue' functions are attached to rural land resources, farmers are increasingly seen as potential performers of 'blue services'. These developments are taking place in a Dutch societal context of increasing land scarcity and land value, and competing functional claims. Therefore, there is a growing imperative for decision-making on the consequences of spatial flood protection policies.

New policies may have important property consequences for inhabitants and rural property holders, so a focus on rural property rights is justified. In the 1970s, Macpherson (1978) criticised earlier misconceptions of property (e.g. land) as 'things' rather than rights and as 'exclusive' private property. In recent years, more empirical work on property transformations in post-socialist settings, Verdery (2004) has criticised the exclusive focus on the rights aspects - the 'goods' - of property. We should also take into account the role of obligations, risk and liability attached to property, the 'bads' of property. Property should be seen as 'bundles' of rights, obligations and liabilities, of 'goods' and 'bads' (Verdery, 2004; for bundles of rights see von Benda-Beckmann, von Benda-Beckmann, and Wiber, 2006).

Transformations of property regimes or property functions and values may shift the balance between 'goods' and 'bads', as studies on post-socialist transformations have shown (Verdery and Humphrey, 2004). In another societal context, similar shifts may be at stake in transformations of the functions of rural property and related bundles of rights and obligations of property holders. ${ }^{3}$ As security against flooding is rapidly becoming a public good, risks and 'bads' tend to be allocated away from densely populated areas with high economic importance towards areas that have lower population densities and less strategic economic activities. Seeing property as a bundle of rights and responsibilities and as constituted by a complex mix of private and public uses, purposes, functions and expectations has the advantage of allowing a deeper understanding of the renegotiation of property rights. 
In this article, we discuss the case of the Overdiep polder, ${ }^{4}$ where such processes in the framework of 'Room for the River' are now ongoing. The inhabitants of this polder area, located in Noord-Brabant Province along the banks of the river Meuse, have taken the initiative to develop plans for a redesign of the polder. This so-called 'terp plan' (terpenplan) makes retention or rather 'flowing along with the river' (meestromen) possible, while also protecting the property and guaranteeing the future socio-economic continuity of the farmers. ${ }^{5}$

Such local initiatives are quite new in the Dutch water world. ${ }^{6}$ They form the basis for interesting experiments with more inclusive forms of policy-making and planning. However, the points of departure of the negotiating parties are quite different. What the government regards as 'flood protection policy' is, in the eyes of the farmers concerned, primarily a government intervention with both opportunities and threats to their daily life, property and continuity of their farming enterprise. The government priority is to find spatial solutions to flooding by adapting 'green' functions of agricultural land in such a way as to accommodate future use for 'blue' functions. For the farmers, these are primarily negotiations about property rights, future social and economic security, and continuity of their enterprise.

This article is based on our ongoing research on 'Room for the River' in the Overdiep polder. We focus here on how the farmers negotiate their property through this intervention. Starting from the more general theoretical frameworks on property and transformations of rural property laid out in the introduction to this volume, it is our purpose to show that negotiating new, water-related functions of the river landscape touches on crucial property issues. If not addressed and negotiated right from the start, conflicts about property issues may lead to resistance against plans for change. A better understanding of changes related to 'Room for the River' in the small polder (550 ha; picture 1) requires long-term study of the actors involved: inhabitants, government agencies, administrators and other parties. Qualitative social-scientific research methods (e.g. interviewing) are best suited for this type of research. It is not our purpose to generalise on the basis of this study, but rather to understand the role of negotiations about rural property. ${ }^{7}$ We discuss those property issues that were perceived as essential by the farmers.

Experiences with recent Dutch policy changes, from an infrastructural approach (dike enhancement) towards a spatial and more integrated risk approach, are also instructive in a European context. Several countries already have, or are experimenting with, a broad range of measures for protection against river floods, such as retention or 'green rivers'. Germany, for instance, already has much experience with retention areas. Like the Netherlands, the UK shows a shift from flood defence to 'living with floods' and 'making space for water' (Johnson, 2007). A topic of general interest for all countries is the ability of citizens to cope with disasters, and policies that move away from a purely technical security approach towards greater risk awareness and societal capability to cope with disasters. Related to this are debates about desired security levels and the choice between uniformity and differentiation, e.g. between urban and rural areas. The Overdiep case shows that new arrangements for intervening inside the dikes by involving citizens in planning and cooperation between governmental bodies at different levels are a possible way of dealing with flood hazards. New relationships developing between the government and citizens in 'Room for the River' may provide an interesting example for other countries struggling with similar problems. 
The article consists of the following parts: First we introduce the Overdiep polder, its location and population, and the way in which the inhabitants became involved. Next, we shift focus to the value of rural property. What will be the basis for buying out farmers: market or expropriation value? Further, a related problem is discussed: the changing status of land from location inside the dikes towards location outside the dikes as a consequence of the terp plan, and its consequences in terms of compensation and land value. After that we discuss the influence of the elusive concept of 'spatial quality', a second objective of 'Room for the River' next to security. Following this, we deal with a number of issues that relate property issues to uncertainty and farm continuity. Finally, Section 8 presents a short conclusion.

\section{The Overdiep polder: a farmer initiative}

\subsection{The Overdiep polder: an overview}

The Overdiep polder is situated in Noord-Brabant Province, squeezed in between the Bergsche Maas and Oude Maasje (Figure 1). It was the product of the creation of the Bergsche Maas in 1904 to improve the discharge capacity of the river Meuse (Maas). Until the 1960s, the polder was inundated each winter. From the late 1960s, it was largely free from regular inundations. In 1975, 17 farmer families from nearby villages settled there. The polder covers 550 ha, with an additional 180 ha of forelands (uiterwaarden). Nowadays, it belongs to two municipalities: Waalwijk and Geertruidenberg. Before farmers settled there, the badly drained land was used extensively for making hay. Now the polder encompasses 16 farmers (one farmer was bought out some years ago through an anticipatory purchase), a recreational harbour for 340 boats, and an army barrack square. The total population in 2003 was 94 . The current land use and settlement pattern dates from the land reallocations and settlement in the early 1970s (Habiforum, 2003).

Figure 1 The Overdiep polder terp plan

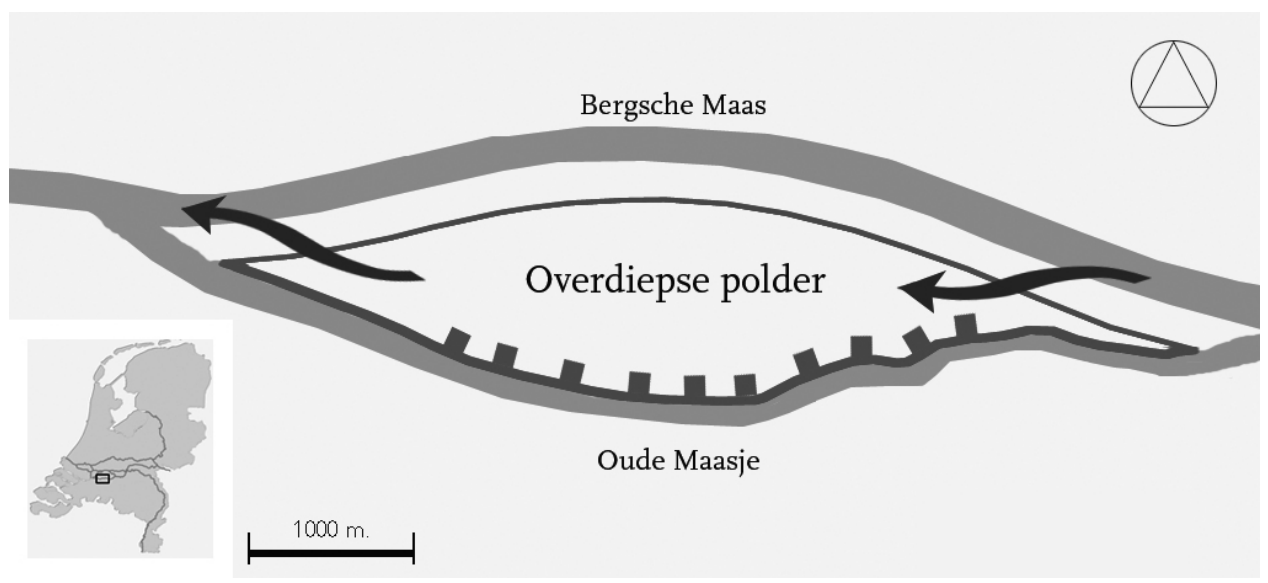


Most current farmers - often children of the initial settlers -are relatively young (30-45 years old), have a dairy farm with 30-80 cows and between 25 and 40 ha of land. Some farmers combine cattle (dairy) farming with other agricultural activities such as cultivation of maize, beets, peas and potatoes. There are also a pig breeder and a breeder of cows for meat production. All farmers except one are members of the same milk cooperative, Campina. Not all land is owned by the farmers who live in the polder: while $60 \%$ is privately owned, some $40 \%$ is worked in leasehold (Habiforum, 2003). Several farmers work land in the forelands or inside the dikes in leasehold. While the state owns the forelands, owners of land inside the dikes in leasehold are primarily small private investors, municipalities, the church and charitable institutions. In the past, farmers who died often bequeathed land to the church. The church still derives income from this land through leasehold contracts for land and milk quota tied to it. Some farmers work land in leasehold in the river forelands; this land is owned by the Public Property Agency (Dienst der Domeinen). ${ }^{8}$ Some landowners live outside the polder themselves. Often they have their land cultivated in leasehold, the contracts of which cover six-year periods that are routinely continued as long as the contracting parties are agreed. Finally, some farmers who live in the polder own, lease or rent agricultural land outside the polder: 76, 68 and 19 ha, respectively (Habiforum, 2003).

\subsection{From 'searching area' to farmer initiative}

In view of its suitable location, the small number of residents and its historical water retention function, the Overdiep polder was a 'searching area' in government studies carried out in the mid-1990s to find more room for the river. Shortly after the 1995 high water, government plans to strengthen and heighten dikes, and construct emergency dikes for the main rivers (the Major Rivers Delta Act; Deltawet Grote Rivieren) were rapidly endorsed by the Parliament and the Council of State. The high water had been a window of opportunity for pushing through dike enhancement (Meijerink, 2005; Wiering and Arts, 2006). However, water experts of Rijkswaterstaat also feared that continued dike enhancement would lead to a loss of public support because of its negative impact on the river landscape. Further, scenarios for climate change, sea-level rise and drops in the land level suggested that it would not be sufficient for the expected discharges. Moreover, the increasingly elevated dikes might give the population a false sense of security. Breach might cause rapid inundation and a 'bath tub' effect, from which residents would not be able to escape in time (RIVM, 2004).

In response to the high water, the government changed the high water norms from 15,000 to $16,000 \mathrm{~m}^{3} \mathrm{sec}^{-1}$ near Lobith (where the river Rhine enters the Netherlands) and 3,650 to $3,800 \mathrm{~m}^{3} \mathrm{sec}^{-1}$ near Borgharen (where the river Meuse enters the Netherlands). ${ }^{9}$ This norm, laid down by law, became the basis of the so-called 'Spatial Planning Key Decision' Room for the River (Ruimte voor de Rivier). ${ }^{10}$ In the meantime, additional studies were made: 'Room for Rhine Branches' (Ruimte voor Rijntakken) in 1998 and Integrated Investigation Downstream Rivers (Integrale Verkenning Benedenrivieren) in 1999 addressed the question how a discharge of $16,000 \mathrm{~m}^{3} \mathrm{sec}^{-1}$ could be transported smoothly without higher dikes.

In the latter, the polder had been identified as a possible retention area. Only a few interest groups had been involved in the study, including representatives of farmer organisation ZLTO and the water boards (waterschappen). ${ }^{11}$ The outcomes were presented by a former delegate of Noord Brabant Province. Most of the farmers were 
surprised and indignant about it. Fearing a threat to the continuity of their farming activities, they exclaimed that they would try and find the best lawyers in the country to block this process (see also Habiforum, 2003; Verhoeven, 2006). ${ }^{12}$

However, the study was a pre-exploration rather than a definite plan. After the meeting with the provincial delegate, two farmers asked the delegate if they could join the brainstorming for finding space for the river in their neighbourhood. They acknowledged the public interest in these flood protection measures, but doubted the government capability to decide quickly on the issue. According to the chairman of the Overdiep farmers' association (Vereniging Belangengroep Overdiepse Polder), 'most people in the polder were more afraid of the government than of the water' (van Rooy, van Luin and Dil, 2006, p.64). They also sensed that litigation could probably delay decision-making, but would also start a long period of uncertainty for their farming enterprises. Therefore, they opted for a critically cooperative rather than a defensive approach. 'In case something has to be done, then preferably quickly and on our conditions', was their reasoning. They established the association of Overdiep farmers to represent their interests in negotiations with the government (see also Verhoeven, 2006) and managed to convince the opposing farmers of this strategy. ${ }^{13}$

After further negotiations, with the help of ZLTO and a financial contribution from the province the farmers developed their own plan that combined living and working in the polder with a 'Room for the River' function. This plan entails agreement on the following: the farmers intend to continue their farm, and are willing to move to terps to be raised along a new dike on the south side of the polder. According to the farmers' plan, only dairy farmers are entitled to a terp. The costs will have to be compensated by the government, which should also compensate those who are willing to move to another location outside the polder or want to terminate farming. The province accepted the plan as a point of departure.

The province intended to combine the objective of water storage with strengthening the agrarian structure by investing in farms to make them economically more sustainable. As several farmer families will leave the polder, their land can be bought up by the government. This land will be partly sold to farmer families that stay in the polder to strengthen their enterprise, and partly used for the new infrastructure needed for the terp plan (terps, dikes, roads). The farmers currently living in the polder have priority over 'outsiders' in buying up land from farmers moving out. ${ }^{14}$

The plan fitted in with an atmosphere conducive to changes in the policy field. A special committee of government representatives, researchers and consultants (Bezinningsgroep Water) was looking for projects that could practise the new water policy. The representative of Noord-Brabant Province proposed the farmers' plan for the Overdiep polder; the committee also had a positive impression of the farmers' plan. Thus, it became one of five so-called 'mirror projects', an 'experimental garden' in which the national government delegates responsibility for a 'plan study' (project design and studies for complying with regulations like Environmental Impact Assessment - EIA) to the province. The point of departure was that residents should be the starting point of the planning process, a new element in Dutch water management planning. The national government provides the primary infrastructure, but increasingly devolves responsibility for implementation to lower governmental bodies. With Overdiep, Noord-Brabant became the first province in charge of delegated responsibility for a river project. 
By late 2007, important progress has been made in the negotiations between farmers, municipalities, water board, province and national government. ${ }^{15}$ However, several important topics for further negotiation are still on the agenda. These issues are primarily about property in relation to the doubts and uncertainties of living in an area that can be used for flooding with an estimated average frequency of once in 25 years. ${ }^{16}$ Propertyrelated issues like the value basis of government purchases and demands for minimal disturbance caused by the trajectory of implementation to farming operations play a major role in the negotiations between farmers and the government. ${ }^{17}$ We will deal with such issues in the following sections. ${ }^{18}$

\section{The value of land: between the need for incentives and the fear of precedents}

The terp plan requires a radical restructuring of the polder, including rebuilding farms and reallocating land. Undisturbed continuation of farming during implementation requires a flexible plan that causes minimal damage to agricultural operations. Land will be needed for new infrastructure (dikes, terps, roads and water-related infrastructure) and expansion of the farms of those who stay in the polder. As only part of the current families will stay, land transactions will be important in implementing the project. Those who stay will have the opportunity to expand. Strengthening farming enterprises is generally seen as the only way of keeping them economically viable in the future, and thus justifying project investments (Habiforum, 2003).

In order to operate as flexibly as possible and to buy out families that decide to move or to stop farming, the province created regulations for buying them out at an early stage, even before finalisation of (national level) political decision-making about either Spatial Planning Key Decision or project (Provincie Noord-Brabant, 2006). These 'anticipatory purchases' (anticiperende aankopen) are intended to give farming families the opportunity to look actively and timely for alternative locations in the Netherlands or abroad, and the province the opportunity to use the land for relocation of enterprises, land exchange and reallocation. Those who decide to stay can sell their real estate (house, stables) to the province and continue using it until they move to a terp (Provincie NoordBrabant, 2006).

However, there are many ways of dealing with such land transactions. ${ }^{19}$ They can be concluded on the basis of either agrarian value (agrarische waarde) or market value, or on the basis of expropriation value (onteigeningswaarde), the former being much lower than the latter. The provincial project director for the Overdiep polder estimates that the difference is $25-30 \%{ }^{20}$ Various parties directly or indirectly involved take different approaches to this issue. The province, the implementing administrative level, takes purchase of land against expropriation value as the point of departure. The Government Service for Land and Water Management (Dienst Landelijk Gebied-DLG), much involved in 'nature development' projects, also in cooperation with Rijkswaterstaat, takes a different approach. Though not directly involved in the Overdiep polder, it keeps a close track of its development. Generally, it regards expropriation as a last-resort measure if the voluntary principle and incentives do not work. According to a spokesman for 
DLG, this choice by the province may well create precedents for future projects in 'Room for the River':

"Eight out of sixteen enterprises [...] will be relocated, another eight will move out. For those who move out or stop, the need to purchase at expropriation value is questionable. If enterprises buy, they will do so against agrarian value. So now the government loses. Buying out farmers in this way creates expectations. The outcomes of value assessment differ between these parties. The basis [of purchasing against expropriation value-D.R./M.W.] is that all damage will be compensated, which is not usual. The existing farming enterprises will be able to expand, so in principle it is not necessary to buy land in this way. But in the end it was decided to treat all Overdiep farmers in the same manner [...]. In projects with a long duration, there would have been another option: DLG buying up property in the surroundings for farmers who intend to leave the polder. But everything had to happen quickly, and expectations have been raised. The farmers have played it very cleverly, and the reply was a quick 'yes'. [...] If there are enterprises that want to move out, why should the government be an intermediary party at all, why not just doing it directly?"21

The farmers, then, demand a purchasing policy based on the expropriation value, and have always been clear on this point (see van Rooy, van Luin and Dil, 2006). However, while farmers demand expropriation value for their property, they fear expropriation as an instrument in implementing the terp plan. For the time being, however, the province takes as its point of departure the possibility of reaching agreements with all farmers on the basis of voluntary decisions. The situation could change if more than ten families decide to stay in the polder. From the beginning, it was clear that there will be eight to ten terps available. There will be no way back for farmers who change their mind after they have signed a contract stating that they intend to move and agree to be bought out. ${ }^{22}$ In the course of 2007, according to our latest information, the number of farmers considering staying is increasing and could even exceed the maximum number of (ten) terps.

Tensions are also involved here between the provincial need for flexibility and incentives for farmers, and the national concern with rules, procedures, risk avoidance and control of project costs. While the province wants farmer families to decide on their future as soon as possible, farmers might want to postpone their decision for personal reasons or to influence negotiations (see below). While the province has opted for buying out against the expropriation value, the national government will have to approve this choice. Thus, these questions about property also touch on the broader and sensitive issue of tensions between central control of the process and decentralised (provincial) implementation.

This issue of the value of land is also closely related to the changing status of land from 'inside the dikes' (binnendijks) to 'outside the dikes' (buitendijks) which we will turn to now.

\section{From land inside the dikes towards land outside the dikes}

Land value is determined mainly by its quality, form, parcelling and elevation, while its location in relation to the farm is also important. Land near a farm has a higher value than a more distant field. Apart from land inside the dikes, the farmers also use some 180 ha 
of foreland (outside the dikes; uiterwaarden) that is regularly inundated during winter (two or three times yearly for several days or weeks). Some four or five farmers use this land. Most of them are state property (Public Property Agency). Generally, it is of lower economic and market value than land inside the dikes, because of the flood risk. Flooding means that the land can be contaminated with pollutants. Along the river Meuse this risk is relatively high. The river contains sewer water from various large cities in Belgium, and washed-away nutrients from fertilisers used in agriculture. These can cause damage when farmers use land outside the dikes for crops or animals; the products are considered a health risk. Therefore, farmers will use this land less intensively; they can better control arable land inside the dikes.

Implementation of the terp plan raises an important question related to the valuation of land as property. The plan will formally turn all land currently located inside the dikes into land 'outside the dikes'. The question, therefore, is: how to value this land after the plan has been realised? The answer can be found in the 'regulations' drawn up by the farmers and the province. However, these leave much room for further negotiation, interpretation and debate.

The province will bring land inside and outside the dikes into a land rearrangement. The objective of this reallocation is to give owners and tenants land near their farms. This means that the future terps and farm land must be divided in such a way that each farmer can obtain a suitable parcel. Reduction of the number of enterprises to eight or nine would make reallocation in accordance with farmers' priorities easier: they want to receive land close to their house and stables, to enable grazing. In case, more farmers would prefer to stay in the polder, land allocation could only take place in the shape of very long plots stretching out across the polder over almost $1 \mathrm{~km}$. This would seriously complicate putting the cows out into the pasture. They will not cover the distance across such long plots; part of the grazing land would remain unused.

Because of the new function of water retention, land inside and outside the dikes will have the same value; the value of the former will decrease. The expected frequency of flooding is once in 25 years. It is, of course, uncertain in which season flooding will occur. High water during the cropping season is rare; winter or early spring is more likely. Therefore, the damage will probably be limited. It is also difficult to estimate damage from remaining dirt and slurry, and to fences and watercourses. Therefore, experts will assess the value decrease. This assessment includes all relevant aspects such as damage and consequential losses. There were two possible ways to compensate such damage. The first option was that farmers would receive a one-time compensation for all future damage. They could then invest this money directly or save it. The alternative is compensation payment after each flooding event. The second option was to set up a special damage regulation for 'Room for the River'. In such a regulation, farmers will be compensated for damage after each flooding. Damage will be assessed by using existing regulations for compensation. Though there will probably hardly be any damage because the income loss will be compensated, the farmers want a 100\% compensation regulation: compensation for all yield loss and other damage.

Two problems emerge here that complicate the issue: first, the actual meaning of ' $100 \%$ compensation' and, second, the relationship between 100\% compensation and recognition of the decreasing value of the land. As to the first, with this $100 \%$ 
compensation, the farmers think that their income loss will be zero. But that is not true, according to the farmers' spokesman:

"Take maize that could be harvested next week; after a flood it will be lost. The expert will come and assess $100 \%$ compensation on the basis to his standard booklet. These are based on old prices, not on current ones. On this basis the farmer will get $€ 550$ per hectare for his lost maize. But he has to buy maize for his cattle against market prices: $€ 750$ per hectare. As $€ 200$ per hectare will not be compensated, the farmer will lose money. For ten hectares this will amount to $€ 2,000$; not dramatic but still money." 23

As to the second issue: though farmers tend to think that they benefit from a $100 \%$ compensation regulation, the reality may be different. Our spokesman:

"If farmers say 'we want $100 \%$ compensation', they forget that they will not be compensated then for the land value decrease [which he estimates at around $20 \%$-D.R./M.W.] because there is no value decrease. Yet most farmers insist on $100 \%$. One farmer asked: 'What about the costs for cleaning the ditches silted up after inundation? Who is going to do that?' I told that such items could best be accounted for in the value decrease of the land [...] Crucial items like cow feed and crops have to be incorporated in a damage regulation, these are the big calamities. But remaining issues should be incorporated in value decrease of the land. They forget the crucial relation of this with expansion of the farms. If you do not get your value decrease compensated in additional land [of those who have moved out-D.R./M.W.], candidates for the land will come from outside. In fact, the current farmers have to scale up to $30-40$ ha and 80-90 cows in order to have economic prospects." ${ }^{24}$

The treatment expenses of an event-based way of compensating damage will probably be higher, as the damage of each event will have to be investigated. This is therefore not the preferred option of the province and the national government. The government aims at categorising such events as 'normal entrepreneurial risk' under existing procedures that address compensation of the complete damage caused by flooding beforehand. In earlier negotiations, the national government had offered allowance for a $5 \%$ land value decrease, which was not acceptable to the farmers. The farmers claimed a much higher percentage but did not want to fix it at an early stage of the negotiations. ${ }^{25}$

In the meantime, farmers have chosen the option of $100 \%$ compensation for each inundation, which means that they will probably not be compensated in additional land. It was agreed that the norms to be used for compensation will be adapted on a yearly basis. $^{26}$

\section{Property and 'spatial quality'}

The main objective of 'Room for the River' is increasing protection against flooding. However, the programme has another objective: increasing the 'spatial quality' of the river landscape. 'Spatial quality' was introduced into Dutch spatial planning as a policy objective in the 2005 'National Spatial Strategy' (Nota Ruimte) of the Dutch Ministry of Housing, Spatial Planning and Environmental Management. ${ }^{27}$ Spatial quality covers notions of functionality (use value), attractiveness (perception) and sustainability (future quality) at the same time. This makes it a very vague and elusive notion that can be interpreted in many ways. Actually, it has to be vague, so as to leave room for multiple and changing interpretations depending on the situation. 
In 'Room for the River', combinations of water-related and other functions within the framework of a dual objective of security (veiligheidsopgave) and spatial quality (ruimtelijke opgave) should make the Dutch river landscapes more viable, sustainable and attractive. According to the Ministry of Transport, Public Works and Water Management (MVW, 2007), 'improving spatial quality is now a second objective in solutions for safety problems'.

How has the use of the concept of 'spatial quality' influenced the process in the Overdiep polder? For the total of around 40 'Room for the River' projects a so-called 'Q-team' (the landscape quality team; landschapskwaliteitsteam) has been formed, consisting of 14 people. From around 2006, spatial quality began exerting influence on the process in the Overdiep polder. The first contacts with the landscape architect (the national landscape adviser) did not run smoothly. According to the farmer spokesman, implementation of 'spatial quality' brings new players into the project, influencing the outcome. Thus, the landscape architect came up with ideas, implementation of which would run counter to the ideas and preferences of the farmers because of the large area of high-quality land needed. Examples are dike design, slope of the terps, the enlargement of the quay of the polder with added 'nature fringes' (around $20 \mathrm{ha}$ ) and the restoration of a former natural drain in the polder, the Dusselse Gantel (around $40 \mathrm{ha}$ ). The spokesman:

\begin{abstract}
"The architect said this would be very beautiful. We tried to make him understand that, for farmers, beautiful is not always functional. How many hectares of land are fragmented by this plan? [....] We have made clear that this will remain an agricultural polder, but they do not listen. They just continue repeating the same story: 'I still think that this would be beautiful.' We have tried to make clear that we objected to the fact that they had made a layout for the polder without any consultation with the farmers. We have offered twice to have a look at what they were making but that never happened." 28
\end{abstract}

The spokesman stresses that, contrary to the point of departure of the terp plan, consultation at the design stage did not take place; the architect did not even visit the polder. According to the farmers, interpretations of 'spatial quality' that do not sufficiently take into account the agricultural function may threaten this function of the polder as agreed upon in the initial plans. The loss of high-quality agricultural land is especially feared: some 120 ha will be impacted by the terp plan and its spatial quality elements. As it has been agreed upon that, on balance, the project should not cause any net loss of agricultural land (and, for the farmers, should even lead to a small increase of their enterprise), the farmers wonder whether it is realistic to allocate so much land to the 'spatial quality' functions.

After fierce discussion between farmers and project officials about these and other issues in a project steering committee meeting in 2007, a partial compromise was reached. The farmers have given way on a number of issues like the slope of the terps (determined by the need for optimal water flow) and the partial restoration of the old natural drain. All reduce the total area of farmland or cut through the holdings (the drain and infrastructure for access to the landscape).

However, they are determined not to give way on another issue: terp design. A layout for the terps has been made by the Q-team. The plan foresees a strip of terp land planted with trees ( 0.5 ha; $25 \%$ of the terp area) all around. The architect stated in mid-2007 that all terps must have the same layout. The farmers disagree, as they do not want their farms to be completely surrounded by trees and want flexibility in the layout rather than 
identical terps. They fear the possible impact of this plan on ventilation (manure smell), sunlight and animal welfare, and a possible breach of existing regulations on these points. They also want the stable to be close to the farm and visibility of the farm on the terp. According to the farmers' spokesman, the inhabitants were denied any opportunity to express their views or preferences. There has been no serious discussion of alternative options nor reaction to their critical questions: 'everybody has something to say about what it should look like. We, the people who will live and work here, are the only exception. They have never asked us anything about this.' Sometimes the farmers feel that they have become a neglected part of what the spokesman calls an 'employment project for expensive consultancy firms'. ${ }^{29}$

\section{Same rights, not equal}

Initially, the board of the farmer association of the Overdiep polder realised that representing the interests of all farmers was crucial in elaborating the various options for the terp plan and making them fit into 'Room for the River'. Effort was especially geared to getting all farmers 'on board', even those who intended to move and had apparently less interest in the outcomes of the design process of the terp plan. Although discussions about design options were not very relevant for them, negotiations about procedures and compensation are. The strategy was to focus on these after reaching general agreement on the terp plan.

Though the province intends to give farmers equal treatment, in practise this will be difficult; the starting point for each farmer is different. The plan will provide a new dike along the Oude Maasje (see Figure 1) and eight to ten terps for the new farms. The dike along the Bergsche Maas will be lowered and an inlet and outlet made at the western and eastern part of the polder. The farmers negotiated 'new for old' (the ability to build a new farm against selling their old farm); farmers who intend to move will be compensated. However, the number of farmers who can stay is limited. If more farmers want to stay than is possible, free choice and equal treatment will come under pressure.

The need on the part of the province for clarity about who moves and who stays, in combination with the various farmer intentions, strategies and initiatives in dealing with the terp plan, may be a source of actual differentiation of farmers in terms of opportunities for negotiating their future. There is a fixed budget ( $€ 89$ million) for plan study ( $€ 3$ million) and realisation of the terp plan ( $€ 86$ million), including the anticipatory purchase from one farmer in 2006. Later, extra money became available for other anticipatory purchases. However, the farmers did not know the provincial budget and the exact purchasing strategy. Hence, rumours started circulating about the assumed intentions of farmers (to move or stay), their strategies and secret dealings with the government. Even our farmer spokesman does not know the real intentions of all farmers. There were also rumours about the role of the province, its passive attitude in buying farms and its tendency to underbid.

Another relevant aspect is the gradually emerging division of farmers into those who wish to stay, those who have already terminated dairy farming and those who intend to move out. Those who want to stay have to negotiate a good price for their land, farm and stables, sufficiently high to buy newly parcelled land, a terp, and some extra land for realising an economically viable enterprise. Some of those who have terminated dairy farming see new opportunities in the terp plan. Farmers who decide to move to another 
location in the Netherlands will be compensated with land: 30-40 ha per family, and another 5 ha as additional compensation. Farmers who intend to migrate and restart abroad (Denmark, Canada and Portugal) will be bought out in such a way as to make this locally feasible. There are also differences between farms in terms of property rights (ownership or leasehold), crops cultivated, kind and number of animals, and value of infrastructure. In addition, the location of the current farm is important. Some farmers have their farm where the new dike will be built; others have their farm in the middle of the polder or near the forelands along the Bergsche Maas. Land rearrangement and the new parcelling will be crucial. A farmer who lives where the new dike will be constructed and wishes to stay might claim a terp near this place. The spokesman:

"We must be honest, not all farmers are equal. If terps are going to be built along the dike as planned, those who live there now and intend to stay will prefer to keep their own land. It will be extremely difficult then for another farmer to claim a terp there. The province stated that 'all farmers have equal chances' [....] In fact, all may have equal rights but not equal chances. This awareness of existing differences becomes increasingly felt as we move towards a final choice [whether to stay or move-D.R./M.W.]."

Finally, the group of farmers is not homogeneous in terms of household composition, enterprise ownership, ambitions, objectives, and thoughts and expectations about the plans. Some enterprises, for instance, are owned by brothers who see the terp plan as an opportunity to split the farm. In short, each farmer has a different starting position, strategy and different objectives. Much depends on the negotiation process between each farmer individually and the province. A newly emerging complication is that, as the moment for deciding comes closer, some farmers who had already given up farming activities (cattle for meat production) but see new opportunities arising, are again considering claiming a terp. Though this contradicts the earlier farmer decision to make terps available to dairy farmers only, they still feel entitled to a terp because they live in the polder.

\section{Property, uncertainty and continuity of the farm}

The choice farmers have to make between staying and moving out is complicated by crucial issues that have not primarily to do with the future prospect of 'living with water' but rather with the future of property and continuity of the farming enterprise, property transfer across generations (inheritance) and the presence or absence of children who are capable and willing to take over, as well as with social networks, kinship and family relations. ${ }^{30}$ Let us take the issue of continuity of the enterprise first. Continuation of production may require investments in farm infrastructure to increase production capacity (e.g. stables) or fulfil legal requirements pertaining to environmental protection or animal welfare (manure treatment; stables for 'cattle welfare'). While the project puts pressure upon farmers not to engage in such investments shortly before project implementation, the uncertainty about future options inside or outside the polder may lead farmers to continue investing:

There is one pig farmer in the Overdiep polder. While the terp plan was already developing, the municipality had given him a building permit for expanding his enterprise (the phased building of two pig stables and a manure silo). One stable and the silo had already been built. During exploratory talks with project 
representatives, the farmer stated that he was not really eager to leave the polder, but willing to negotiate alternatives. He stressed that he wanted to return to his area of origin on the sandy soils of Noord-Brabant Province. The provincial project director started looking for a location (a pig farm, the owner of which was willing to be bought out), and found one that fulfilled the farmer's wishes. But soon they found that the provincial regulations pertaining to agricultural reconstruction forbid establishment of new pig farms in this region. The province was not willing to make an exception in this case. As looking for another location takes time and was not the preference of this farmer, and the last building permit was about to run out, he decided to continue building to guarantee the continuity of his farm. Though other farmers and the project see this as loss of capital (the new infrastructure will increase the sum needed for buying this farmer out), they also understand that the farmer cannot run the risk of further stagnation of his enterprise.

Issues of property transfers from one generation to another, and of distribution of property among heirs may also influence decision-making about farming. As to the first, in the following case the combination of uncertainty about long-term continuity of the farm, due to the young age of the children, and suddenly changing family circumstances may be an important source of doubt about whether to stay or move away.

One farming family, a married couple with two children, has a dairy farm with 25 ha of land (15 ha ownership, 10 leasehold) and some 60 cows. The husband is married to the daughter of a farm owner elsewhere in the province. It is very unclear whether their young children (both of secondary school age) will develop the skills and ambition to take over the Overdiep farm. Actually, the moment to decide whether to stay in the polder or move out comes too early. A further complicating factor is the recent death of the wife's father (the owner of a farm elsewhere). As a consequence of his passing away, the widow will stay behind alone. The woman of the Overdiep family is the sole inheritor and, moreover, feels responsible for the wellbeing of her mother. Thus, while the issue of future transfer to the children of the Overdiep family is still very unclear, changing family circumstances may put pressure on the family to decide whether to sell all their property in the Overdiep polder and continue farming on the other farm or not.

In the following case, the husband and wife have different ideas about the future:

One young farming family, the husband of which has recently taken over the farm from his father, has seriously considered moving out of the polder and migrating abroad. For the husband, Denmark was a strong candidate for starting a new farm. He had spent some time there for a practical period and has two friends who have also established their farms there and whom he regularly visits. While he has, in fact, already made up his mind about it, his wife does not want to take the step, because she fears social isolation in a foreign country far away from the family and established social networks in the Overdiep polder.

In the following case, inheritance conflict is a crucial factor in decision-making about the future.

The first farmer who was bought out, and migrated to Canada to start a farm there, had for some years been planning to emigrate. He was a young farmer when his father died, some twelve years before, and had taken over the family farm; his brother (he has one brother and two sisters) was a wage labourer. However, soon after their father died, the brother claimed part of the farmland, expressing his wish to become a pig farmer. Their father had not left a clear will covering division of the inherited property between the children. The 
quarrel caused a rift between him and his brother and sisters. The claiming brother did not get what he wanted, sold his house and migrated to Denmark. Hearing of the farming opportunities in that country, the brother farming in Overdiep became attracted to the idea of migrating as well. His young children would probably have a better future abroad, where farmland is less scarce than in the Netherlands. He went to Canada for a first orientation, and decided to prepare for emigration. However, there were two complications. First, he feared that the new flood risk policy of 'Room for the River' would make his enterprise unsaleable. Second, one thing his father had stated in his will was the condition that, if the farm should be sold within ten years after his death, the proceeds would have to be shared between all the children. During initial talks with the province about the terp plan, he soon felt that 'Room for the River' was an opportunity rather than a hindrance. He asked for another nine months to think about his future. When this period had passed, he quickly reached agreement with the province about being bought out. He had one further condition: signing the contract with the province on 3 January 2005, the date on which the ten-year period elapsed.

\section{Conclusions}

The recent changes in Dutch flood protection policy, from an infrastructural focus towards a combination of spatial and infrastructural protection measures, have led to the formulation of new solutions in the framework of 'Room for the River'. Where people and land have long been separated from rivers by the dike system, these solutions of 'living with water' establish new interactions between people and water. In a small, densely populated country where space is scarce, these changes have a direct bearing on rural property issues. In a highly urbanised and industrialised society, such changes attach new values to rural property. Security against flooding is rapidly becoming a public good; the risks and the 'bads' tend to be allocated away from densely populated areas with high economic importance towards areas with lower population densities and less strategic economic activities. The new solution is based on assigning 'blue' functions to rural property and performance of 'blue services' by rural property holders.

However, these shifts require completely new approaches to policy-making, planning and implementation. 'Room for the River' requires a style based on the determination to reach negotiated solutions, rather than the hierarchical 'command and control' style characteristic of the government agency Rijkswaterstaat until quite recently. Even though support for more participatory styles seems to be growing, lack of experience with these new approaches and the uncertainties that come with a more open and negotiated process are still major stumbling blocks in putting them into practice.

The Overdiep polder is a first experiment with these new dimensions of flood protection policy. The general conditions for such an experiment seem to be almost ideal: a government in need of local support for its plans, and a small and relatively homogeneous group of farmers willing to negotiate new water-related functions affecting their rural property. We have discussed some crucial property issues emerging in the negotiations between farmers and the government: the value of land; the changes in status and value as a consequence of project implementation; discussions about 'spatial quality'; the inequalities between farmers notwithstanding their-in a formal sense - equal rights; and the relationships between property, uncertainty and (dis)continuity of the farm. 
The property perspective contributes to a deeper understanding of the processes involved. This focus on the rural property dimensions of negotiations about a 'Room for the River' project clearly shows that, for the Overdiep farmers, the terp plan is primarily a mix of opportunities and threats requiring negotiations about rural property. The government was primarily implementing its water policy, but now finds itself in interaction with a group of farmers that took over the initiative, decided to react positively to the government plans, and were clear about their priorities, demands and expectations pertaining to their property right from the start. Sometimes, from government circles the complaint can be heard that the farmers are 'over-demanding'. However, attention to these property issues puts this simplistic view into perspective.

The government, in need of 'success' in its new water policy, has no choice but to engage in serious negotiations with the farmers involved in, and who will be affected by, the terp plan. Moreover, like the farmers, the government will have to accept the uncertainties that characterise this open-ended process. The need for success on the part of the government, in combination with the strong role of farmers in developing the terp plan, seems to have given the farmers a strong negotiating position about their property. However, in the coming period, final decisions will have to be made about staying or moving, compensation and all other property issues that form the core of negotiations about the terp plan. It is only at that stage that we will be able to draw more definitive conclusions about the outcome of this process.

\section{References}

von Benda-Beckmann, F., von Benda-Beckmann, K. and Wiber, M.G. (2006) 'The properties of property', in F. Benda-Beckmann., K. von Benda-Beckmann. and M.G. von Wiber (Eds), Changing Properties of Property. New York, NY; Oxford, UK: Berghahn Books. pp.1-39.

Habiforum (2003) Spiegelproject Overdiepse Polder. Rapportage Verkenning. Gouda, The Netherlands: Habiforum.

Johnson, C. (2007) 'Aspiration and reality: flood policy, economic damages and the appraisal process', Area, Vol. 39, pp.214-223.

Kwadijk, J., van Gemert, N., van Asselt, M., van Deursen, W., Middelkoop, H., Buitenveld, H., Haasnoot, M. and Rotmans, V. (2001) 'Maatgevende afvoeren, onzekerheden en wereldbeelden', Stromingen, Vol. 7, pp.5-17.

Macpherson, C.B. (1978) Property. Mainstream and Critical Positions. Oxford, UK: Basil Blackwell.

Meijerink, S. (2005) 'Understanding policy stability and change: the interplay of advocacy coalitions and epistemic communities, windows of opportunity, and Dutch coastal flooding policy 1945-2003', Journal of European Public Policy, Vol. 12, pp.1060-1077.

Ministry of Transport, Public Works and Water Management, MVW (2006) 'Spatial planning key decision 'Room for the River', The Hague, Ministerie van Verkeer en Waterstaat, Available at: www.ruimtevoorderivier.nl (accessed 24 May 2007).

Ministry of Transport, Public Works and Water Management, MVW (2007) 'Technisch rapport ruimtelijke kwaliteit', De ruimtelijke kwaliteit van veiligheidsmaatregelen voor de rivier.

Provincie Noord-Brabant (2006) 'Planstudie rivierverruiming Overdiepse Polder', Anticiperende aankopen, Provincie Noord-Brabant (project document).

RIVM (2004) 'Dutch dikes, and risk hikes. A thematic policy evaluation of risks of flooding in the Netherlands', Extended Summary. Bilthoven, Netherlands Environmental Assessment Agency, National Institute for Public Health and the Environment (RIVM). 
Roth, D. and Warner, J. (2007) 'Flood risk, uncertainty and changing river protection policy in The Netherlands: the case of 'calamity polders', Tijdschrift voor Economische en Sociale Geografie, Vol. 98, pp.519-525.

Roth, D., Warner, J. and Winnubst, M. (2006) Een noodverband tegen hoog water. Waterkennis, beleid en politiek rond noodoverloopgebieden, Wageningen, The Netherlands: Wageningen UR.

Samuels, P., Klijn, F. and Dijkman, J. (2006) 'An analysis of the current practice of policies on river flood risk management in different countries', Irrigation and Drainage, Vol. 55, pp.141-150.

TeBrake, W.H. (2002) 'Taming the waterwolf: hydraulic engineering and water management in the Netherlands during the Middle Ages', Technology and Culture, Vol. 43, pp.475-499.

Toonen, T.A.J., Dijkstra, G.S.A. and van der Meer, F. (2006) 'Modernization and reform of Dutch waterboards: resilience or change?', Journal of Institutional Economics, Vol. 2, pp.181-201.

van der Most, H. and Wehrung, M. (2005) 'Dealing with uncertainty in flood risk assessment of dike rings in the Netherlands', Natural Hazards, Vol. 36, pp.191-206.

van Rooy, P., van Luin, A. and Dil, E. (2006) Nederland Boven Water. Praktijkboek Gebiedsontwikkeling. Gouda, The Netherlands: Habiforum/Nirov/Vrom.

van Stokkom, H.T.C., Smits, A.J.M. and Leuven, R.S.E.W. (2005) 'Flood defense in the Netherlands: a new era, a new approach', Water International, Vol. 30, pp.76-87.

Verdery, K. (2004) 'The obligations of ownership: restoring rights to land in postsocialist Transylvania', in K. Verdery and C. Humphrey (Eds), Property in Question: Value Transformation in the Global Economy, Oxford, New York, UK: Berg, pp.139-159.

Verhoeven, I. (2006) 'Alledaags Politiek Burgerschap en de Overheid', in P.H. Meurs, E.K., Schrijvers and G.H.D. Vries, (Eds), Leren van de Praktijk. Gebruik van Lokale Kennis en Ervaring voor Beleid, Amsterdam/'s Gravenhage: Amsterdam University Press/ Wetenschappelijke Raad voor het Regeringsbeleid.

van der Werff, P. (2004) 'Stakeholder responses to future flood management ideas in the Rhine River basin: nature or neighbour in Hells Angle', Regional Environmental Change, Vol. 4, pp.145-158.

Wiering, M.A. and Arts, B. J. M. (2006) 'Discursive shifts in Dutch river management: 'deep' institutional change or adaptation strategy?', Hydrobiologia, Vol. 565 pp.327-338.

Wiering, M.A. and Driessen, P.P.J. (2001) 'Beyond the art of diking: interactive policy on river management in the Netherlands', Water Policy, Vol. 3, pp.283-296.

Wiering, M.A. and Immink, I. (2006) 'When water management meets spatial planning: a policyarrangement perspective', Environment and Planning C: Government and Policy, Vol. 24, pp.224-238.

Wolsink, M. (2006) 'River basin approach and integrated water management: governance pitfalls for the Dutch space-water-adjustment management principle', Geoforum, Vol. 37, pp.473-487.

\section{Notes}

${ }^{1}$ Safety along the river Rhine - Nederrijn, Lek, Merwede and Waal - and the downstream part of the Meuse has to meet the legally required norm in 2015. For the river Rhine this means an average high water discharge of $16,000 \mathrm{~m}^{3} \mathrm{sec}^{-1}$ near Lobith and for the river Meuse $3,800 \mathrm{~m}^{3} \mathrm{sec}^{-1}$ near Borgharen.

${ }^{2}$ While safety is the first objective of 'Room for the River', a second one is 'spatial quality', associated with the valuable features of landscape, nature and environment, and cultural history.

${ }^{3}$ Thus, farmers in the Netherlands who receive subsidies for performing nature conservation tasks on their land are often confronted with rigid bureaucratic procedures that one-sidedly allocate risk and blame for not meeting quantitative targets (e.g. growth of the number of bird species) to 
farmers and fine them accordingly. Often, farmers who were fined met all the contractual criteria for conservation-based management but failed due to factors that they cannot influence: bird species that do not return, or the groundwater level (see NRC Handelsblad, 19 January 2008).

${ }^{4}$ A polder is an area of low elevation surrounded by dikes, in which the (ground)water level is controlled by pumping devices, originally windmills.

5 A 'terp' (mound) is an artificially created elevation in the landscape. Especially in the northern Netherlands, terps were used to protect human settlement against flooding, before dikes took over this protective function.

${ }^{6}$ In stating this, we realise that in the past, before the emergence of a centralised agency responsible for water, flood protection and the related infrastructure, the Dutch institutional landscape with its thousands of water boards (waterschappen) was characterised by a local focus, initiative and capacity to locally negotiate solutions. Radical reorganisation has also changed the water boards (TeBrake, 2002; Toonen, Dijkstra and van der Meer, 2006).

${ }^{7}$ We have followed the development in the polder from 2005. The authors intend to follow the process until finalisation expected in 2014. Especially during the sensitive stage of initial negotiations, it was not always easy to get access to information or discuss developments with the representatives of government institutions or other actors involved. We express our thanks to one of the representatives of the Overdiep farmers, who was willing to regularly share with us his views of and experiences with the process.

${ }^{8}$ Dienst Domeinen is a section of the Ministry of Finance.

${ }^{9}$ In the early $1990 \mathrm{~s}$, the design discharge norm was reduced from 16,000 to $15,000 \mathrm{~m}^{3} \mathrm{sec}^{-1}$, under the influence of 'green' societal pressures in favour of protection of landscape and cultural values by minimising engineering interventions (dike reinforcements). After 1995, it returned to $16,000 \mathrm{~m}^{3} \mathrm{sec}^{-1}$, and estimations of peak discharges of 18,000 or even $20,000 \mathrm{~m}^{3} \mathrm{sec}^{-1}$ started influencing policy debates (see Roth and Warner, 2007).

10 A Spatial Planning Key Decision (Dutch PKB - Planologische Kern Beslissing) is the outcome of national-level spatial planning (see MVW, 2006).

11 ZLTO (Zuidelijke Land- en Tuinbouw Organisatie) is a farmers' reperesentative organisation working in three southern/eastern provinces of the Netherlands: Zeeland, Noord-Brabant and Gelderland. As such it was part of a 'sounding board' group for the plans and hence informed about them. What is important here is that the Overdiep farmer community was only indirectly represented at this stage through its linkages with this organisation.

12 Interview, spokesman of the Overdiep farmers (Waspik, 27 May 2005).

13 Interview, spokesman of the Overdiep farmers (Waspik, 27 May 2005).

14 As the project has attracted much public attention, farmers from other areas have already shown interest in buying land and a terp in Overdiep. This concerns three farmers from Noord-Holland Province, who feel more and more restricted by increasingly influential European regulations, especially the bird and habitat regulations.

15 Next to national government, province and municipality, water boards are an important element of the Dutch administrative system.

${ }^{16}$ In some cases the prospect of 'living with water' seems to be a major factor in decision-making by farming families on whether to stay or move out of the polder; see also below.

17 Interview, René Peusens, project director Overdiep Polder for Noord-Brabant Province (Den Bosch, 28 September 2006).

18 The ownership of milk production quota, crucial for dairy farmers, does not play a prominent role here. Moving the quota is possible and buying or selling quota is part of the general negotiations about purchases. In addition, the milk quota system will probably be abolished in 2014 or even earlier.

19 The Coordination Team Property (Coördinatie Team Vastgoed; CTV) has been established to advise on land acquisition. Members are governmental bodies like Rijkswaterstaat, Dienst Landelijk Gebied and other parties involved in property issues. In 'Room for the River', the 
'puller' of a project (in this case Noord-Brabant Province) designs an acquisition strategy. Final determination is in the hands of the national programme directorate (PDR), with advisory input from CTV.

20 Interview, René Peusens (Den Bosch, 28 September 2006).

${ }^{21}$ Interview Willie Tiggeloven, DLG (Arnhem, 13 November 2006).

22 Interview, René Peusens (Den Bosch, 28 September 2006).

23 Interview, spokesman of the Overdiep farmers (Waspik, 8 March 2007).

24 Interview, spokesman of the Overdiep farmers (Waspik, 8 March 2007).

25 Interview, spokesman of the Overdiep farmers (Waspik, 10 November 2006).

${ }^{26}$ Interview, spokesman of the Overdiep farmers (Waspik, 29 June 2007).

27 'National Spatial Strategy' of the Ministry of Housing, Spatial Planning and Environmental Management; accessed on 11 February 2008, see http://www2.minvrom.nl/pagina.html? id $=7348$.

28 Interview, spokesman of the Overdiep farmers (29 June 2007).

${ }^{29}$ Interview, spokesman of the Overdiep farmers (12 October 2007).

${ }^{30}$ Interview, spokesman of the Overdiep farmers (various dates). 